\title{
Is native tissue always better?
}

\author{
Osami Honjo, MD, PhD
}

\footnotetext{
From the Division of Cardiovascular Surgery, Department of Surgery, Labatt Family Heart Centre, The Hospital for Sick Children, University of Toronto, Toronto, Ontario, Canada.

Disclosures: Author has nothing to disclose with regard to commercial support.

Received for publication Feb 29, 2016; accepted for publication March 1, 2016; available ahead of print April 2, 2016.

Address for reprints: Osami Honjo, MD, PhD, 555 University Ave, Toronto, Ontario, M5G1X8 Canada (E-mail: osami.honjo@sickkids.ca).

J Thorac Cardiovasc Surg 2016;152:e39-40

$0022-5223 / \$ 36.00$

Copyright (C) 2016 by The American Association for Thoracic Surgery

http://dx.doi.org/10.1016/j.jtcvs.2016.03.009
}

The right aortic arch in the setting of hypoplastic left heart syndrome is extremely rare. On the basis of previous case reports, ${ }^{1}$ the right aortic arch commonly forms a vascular ring with the aberrant left subclavian artery, the diverticulum of Kommerell, and a large arterial duct. Matsushima et $\mathrm{al}^{2}$ reported an innovative reconstructive approach to this rare aortic arch condition in which the diverticulum of Kommerell was used as a part of the Norwood aortic arch reconstruction. After dividing the arterial duct and aberrant left subclavian artery, the retroesophageal portion of the diverticulum of Kommerell was pulled back rightward and anterior to the esophagus and trachea. The diverticulum of Kommerell then was used as a lesser curvature of the new aortic arch with a small piece of treated autologous pericardium as an extension to secure enough space underneath the reconstructed aorta to the right pulmonary artery and bronchus.

The greatest advantage of this technique is to remove all the retroesophageal component of the diverticulum so there is no concern of future tracheal or esophageal compression by the residual diverticulum of Kommerell sitting behind the trachea and esophagus. Among patients who previously underwent vascular ring surgery, $5 \%$ to $10 \%$ experience recurrent symptoms, and the residual and sometimes bulky diverticulum of Kommerell is the most common cause of recurrent symptoms requiring surgical reintervention. Given those patients with hypoplastic left heart syndrome who eventually have a cavopulmonary connection physiology, it is important to ensure that there is no concern of major airway compression by the residual diverticulum. Resection or relocation of the diverticulum would be recommended as a part of the Norwood aortic arch reconstruction in such cases.

The second potential advantage raised by the authors is the growth potential of the reconstructed arch where most of the reconstruction was done with native tissue connections using the diverticulum itself. This is based on the assumption that the vessel wall characteristics of the diverticulum of Kommerell are similar to those of the aorta. I have to raise a word of caution on this technique

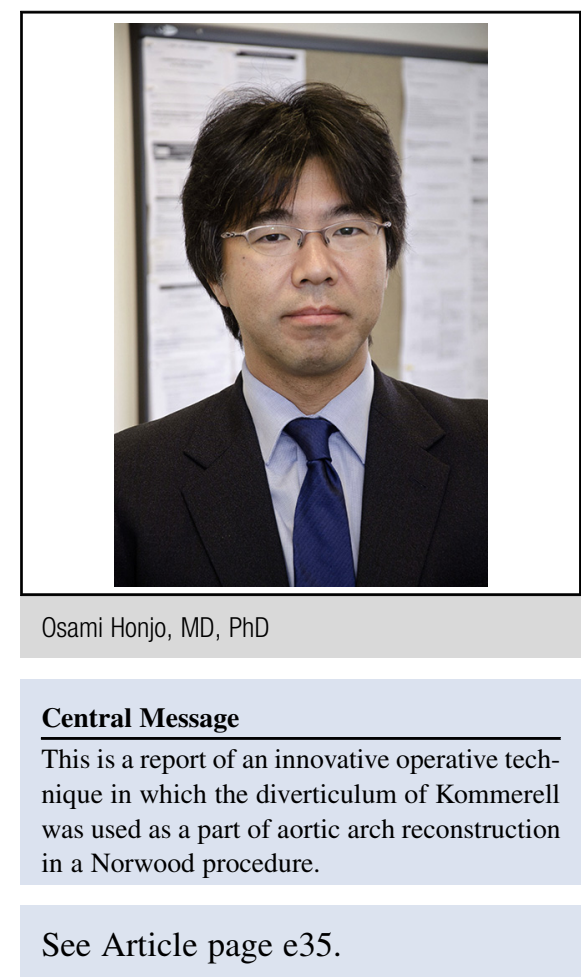

after reading a recent clinical study from Luciano et al, ${ }^{4}$ who suggested routine resection of the diverticulum of Kommerell at the time of vascular ring repair. In their series of 12 patients, $3(50 \%)$ of 6 available pathologic specimens showed obvious cystic medial necrotic changes with fragmentation of elastic lamellae. ${ }^{4}$ Another patient's specimen had a focal area of cystic medial necrosis. This raises a concern over using the diverticulum wall as a part of the reconstructed aorta, which will be exposed to the high-pressure system for the rest of the patient's life. Those pathologic findings, which also were pointed out by Tanaka et al, ${ }^{5}$ may explain the somewhat high rates of dissection, aneurysmal formation, and rupture of the diverticulum of Kommerell in the long term.

Overall, Matsushima et $\mathrm{al}^{2}$ should be congratulated on this innovative reconstructive technique for the complex aortic arch anatomy. Relocation or resection of the retroesophageal component of the diverticulum of Kommerell makes sense and has to be the essential component of this type of repair. The use of diverticulum wall as a part of the aortic arch reconstruction is controversial with the concern of potential intrinsic abnormalities of the diverticulum wall. 


\section{References}

1. Patel PM, Bartlett HL, Scholz T, Burzynski J, Behrendt DM, Burkhart HM. Norwood modification in a patient with hypoplastic left heart and a right aortic arch. J Thorac Cardiovasc Surg. 2007;134:1065-6.

2. Matsushima S, Oshima Y, Matsuhisa H. Aortic arch reconstruction using a Kommerell diverticulum for hypoplastic left heart syndrome with a right aortic arch. $J$ Thorac Cardiovasc Surg. 2016;152:e35-7.
3. Backer CL, Mong MC, Russell HM, Popescu AR, Rastatter JC, Costello JM. Reoperation after vascular ring repair. Semin Thorac Cardiovasc Surg Pediatr Card Surg Annu. 2014;17:48-55.

4. Luciano D, Mitchell J, Fraisse A, Lepidi H, Kreitmann B, Ovaert C. Kommerell diverticulum should be removed in children with vascular ring and aberrant left subclavian artery. Ann Thorac Surg. 2015;100:2293-7.

5. Tanaka A, Milner R, Ota T. Kommerell's diverticulum in the current era: a comprehensive review. Gen Thorac Cardiovasc Surg. 2015;63:245-59. 